\title{
Initial fundamentals for the generation of a pre model of phenomenological analysis focused on the concept of violence
}

\author{
Fundamentos iniciales para la generación de un pre modelo de análisis \\ fenomenológico centrado en el concepto de la violencia
}

\begin{abstract}
J. J. Mosquera-Rodas
Abstract-The article proposes an investigation for the construction of a pre-analysis model, based on the phenomenological conception from the psychology referred to by Fisas Vicenç, to then address the construct of violence, based on the cultural perspective from Rojas Blanco, stripping himself from the dualistic conception of gender that arises from the Cartesian philosophical conception, aspect that prevents addressing the issue of violence as a great psychosocial phenomenon, leaving it in a purely legal problem, without transcending the psychological as an alternative solution to the current problem. The methodology used is of a hermeneutical nature, focusing the interpretation on the theoretical position, the statistics are analyzed, as the interpretative scenario related to the topic, using the main elements of the pre-model as a form of empirical application of the same, to the social contexts that require it. For this, then, the interpretative analysis of the primary elements of the family violence category is used, in relation to the various manifestations of this, at the social level. Essentially, the pre-model, its elements and the way of articulating them to the phenomenological world are presented as a result, for a more objective view at the reality of violence in the different scenarios. It is important to refer to the need to transform the perspective of violence from the complex, dissolving the notion of duality that stands around this category at the level of national and international institutions. A more humane and in-depth look at this category allows more objective decisions to be made, about the different issues that emerge around the concept of violence.
\end{abstract}

Index terms - Physical violence, psychological violence, premodel, community, social conflict.

Resumen- El artículo plantea una investigación para la construcción de un pre modelo de análisis, fundamentado en la oncepción fenomenológica desde la psicología referido por Fisas Vicenç, para luego abordar el constructo de violencia, fundamentado en la perspectiva de lo cultural desde Rojas Blanco, despojando al mismo de la concepción dualista de género que surge de la concepción filosófica cartesiana, aspecto este que impide abordar el asunto de la violencia como un gran fenómeno

This manuscript was sent on February 03, 2020 and accepted on June 14, 2020.

J. J. Mosquera-Rodas is with Universidad Cooperativa de Colombia, Bloque Administrativo, Complejo Educativo La Julita - Facultad ciencias sociales y humanas - Colombia (e-mail: jhon.mosquera@campusucc.edu.co.

\section{; M. B. Valencia-Bonilla iD}

psicosocial, dejándolo en un problema netamente legal, sin trascender a lo psicológico como alternativa de solución ante la problemática actual. La metodología que se usa es de naturaleza hermenéutica, centrando la interpretación en la postura teórica, se analizan las estadísticas, como el escenario interpretativo relacionado con el tema, empleando los principales elementos del pre modelo como una forma de aplicación empírica del mismo, a los contextos sociales que lo requieran. Para ello entonces, se recurre al análisis interpretativo de los elementos primarios de la categoría violencia familiar, en relación a las diversas manifestaciones de esta, a nivel social. Esencialmente se presenta como resultado el pre modelo, sus elementos y la manera de articularlos al mundo fenomenológico, para una mirada más objetiva a la realidad de la violencia en los diferentes escenarios. Es importante referir la necesidad de transformar la perspectiva de la violencia desde lo complejo, disolviendo la noción de dualidad que se erige en torno a esta categoría a nivel de la institucionalidad nacional e internacional. Una mirada más humana y a profundidad sobre esta categoría permite la toma de decisiones más objetivas, sobre las diferentes problemáticas que emergen entorno al concepto de violencia.

Palabras claves - comunidad, conflicto social, pre modelo violencia física, violencia psicológica.

\section{INTRODUCTION}

$\mathrm{T}$ HE process of violence at the physiological level has been studied by neuroscience, but beyond the neurophysiological structure that involves this phenomenon, there is the relationship between the contrasted psychobiological events and the psychosociological or context elements that underlie this factor.

In this order of ideas, it is necessary to propose a structural analysis that allows to broaden the conception of the violence construct as an isolated social fact and as an element configured through parenting factors, to a more meaningful perspective

M. B. Valencia-Bonilla is with Universidad Cooperativa de Colombia, Bloque Administrativo, Complejo Educativo La Julita - Facultad economicas, admintrativas y contables- Colombia Is with Universidad Tecnológica de Pereira -Carrera 27-10-02 Barrio Alamos- (e-mail: mabeva@utp.edu.co). 
that allows observing the phenomenon as a constitutive element of the personal violence-social violence relationship, using a pre phenomenological model, applied to statistical results.

\section{MATERIAL AND METHOD}

The research is of a hermeneutical nature with an empirical application in the search for theoretical foundations to generate a pre-model focused on the analysis of the violence factor, understood as a meta-phenomenon or a complex phenomenon. To make these findings, previous statistical analysis of the phenomenon to be investigated is used.

Méthod: The research allows an approach to the hermeneutical analysis from a partly gnoseological perspective, linking to the theoretical context, the different elements of philosophical analysis, from a critical perspective.

\section{FIRST THEORITICAL ELEMENTS OF THE PRE-} MODEL.

These 3 factors (personal violence-social violence-parenting factors) have to do with a more complex view of what we will call the metaphenomenon of violence.

In relation to the metaphenomenal construct, it is seen here as an emerging set of relationships around specific epiphenomena that occur in more complex phenomenological systems and are invisible to conventional analysis, due to the multiplicity of chain factors that arise in the relational processes that are established in psychosocial contexts, as shown in Fig. 1 .

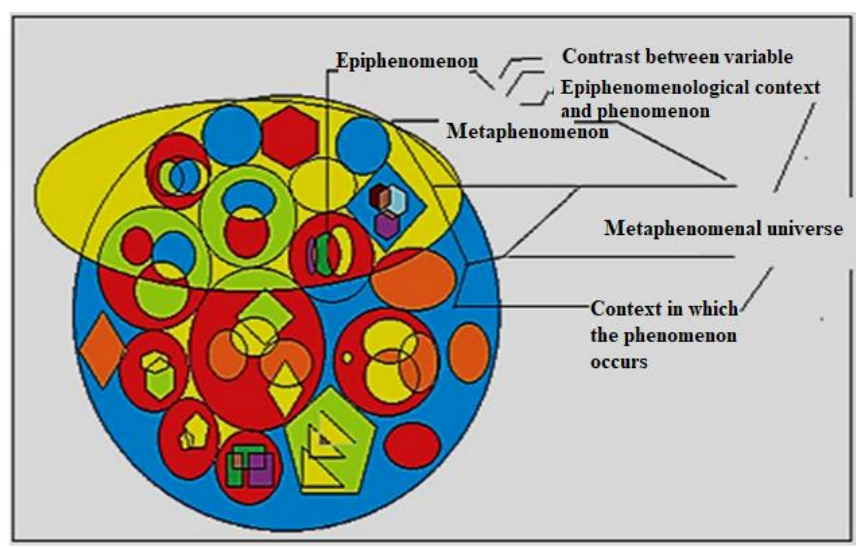

Fig.1. Epi phenomenological ecology of a paradigmatic model.

Let us start from a light description of only some elements to conceive the premodel of phenomenological understanding proposed. The first construct of this has already been determined by Husserl, this being the phenomenon:

One of the most recent ideas about this distancing is that of Edmund Husserl, which gave rise to the phenomenological method as a means of unifying knowledge. According to Husserl, critical awareness begins by means of an epoxhe that we practice in a totally voluntary way about what he calls the natural attitude. The natural attitude according to him consists in believing that all the things that we understand are something existing. What the epoxhe does is to leave in suspence the existence of the things on which we are persuaded in the mental attitude. As a result of this action we are now left alone with what APPEARS AS SOON AS IT APPEARS and what Husserl calls the phenomenon. By virtue of this action we are at a distance from reality, but we gain something more important to know: the phenomenon as a measure of everything that we previously understood as real. (Ramírez, Ramírez, Celedonio, 2002) [8]

Although the philosophical dissertation on the concept of phenomenon is very rich in cognitive nuances, it is very important to specify that the concept of phenomenon is taken from the original idea of Edmund Husserl and for the purpose of this work the reflection that corresponds will be that of: (...) we are now left alone with what APPEARS AS SOON IT APPEARS and what Husserl calls the phenomenon (Husserl cited by Ramirez). By essentially having its own character of reliability, reality then, although distant, manages to be penetrated by the phenomenon that presents it to the conscience to be subjected to reason. The other dissertations enter the field of philosophy and from here the concept of phenomenon will be understood.

The Greek prefix Meta-: $\mu \varepsilon \tau$, indicates that it means "next to", "after", "between" or "with" (RAE) and to achieve the meta phenomenon gramatical copula, understood as a set of phenomena that are "next to", "after", "between" or "with" in constant multi-dynamic relationships that generate orderly chains of cause effects in a particular context, seen the order as a process not as a line of events only.

The second construct is the epiphenomenon that is defined in the context as:

"Given the phenomenon, that is, a fact, an epiphenomenon is another phenomenon that depends on the first, that accompanies the first or that depends on the first, that accompanies the first or is a residue of the first. [7]. This concept related to Democritus is certainly correct in terms of the function of the phenomenon epiphenomenon relationship, but cannot be understood in a unidirectional relationship where the phenomenon is not affected by the epiphenomenon. In psychology, in particular, the human being is a complex being that is affected to a greater or lesser extent by the context, his inner world and the various interactions that emerge in life where both are protagonists. For this reason it is not acceptable at least in this discipline to refer to a unilateral designation of the epiphenomenon.

The metaphenomenological universe is a great category that goes beyond the concept and the construct as they are known, 
while the concept is definable and with a tendency at least unilateral or bilateral at best, and the construct tends to be not definable and in a wide margin it will be very difficult to specify or define it from the classical logic, the great category or the meta category frames the world of terms, concepts and constructs in ordered systems as occurs when nature is observed and especially a forest, which is undoubtedly a micro-universe of beings that live under definable biological principles and operationalized by systemic networks, as Capra refers to it in his text the plot of life.

(...) The perception of the living world as a network of relationships has made thinking in terms of networks expressed more elegantly in German as Vernetzes Denken - in another of the fundamental characteristics of systemic thinking.

This "network thinking" has influenced not only our vision of nature, but also the way in which we speak of scientific knowledge. [2]

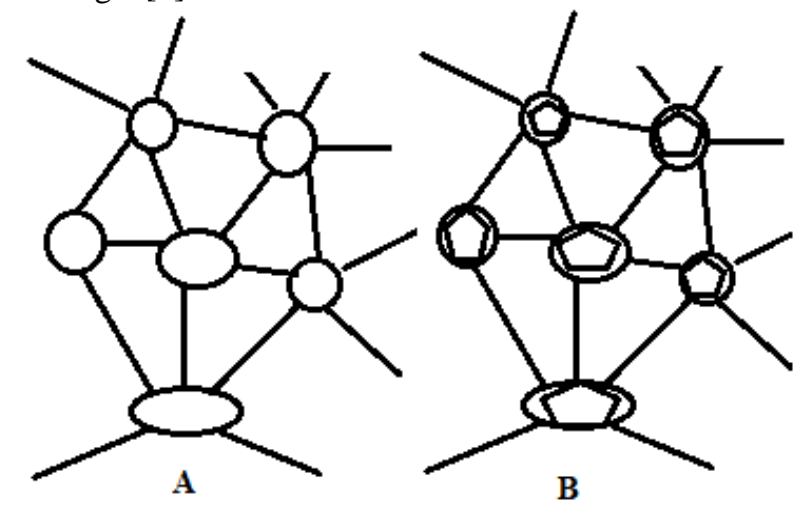

Fig. 2. The change from schemas of objects to relationships. Source: The plot of life Fritjof Capra. P. 24. [2]

The previous figure 2, presented in the book The plot of life, represents not only the view of systems as living entities but also the conception of man as a complex systemic being, and not as a mathematically calculable linear entity as the theory of Classical science still looks at him. This set of networks that are in nature, in human or animal societies and as a posteriori judgment in the human unconscious world. Although proving such an assertion tends to be complicated, think of the ideations of psychotic or schizophrenic patients and the corresponding disorders of the content of thought, which generate a world from the reality lived and the reality they live, this will give an idea of how in the world of thought, reflection and knowledge a similar process also occurs but in function of a precise objective, such as the construction of a scientific theory: think that the vision and the logical and cognitive elucidations of a genius tend to isolate it from the context and generate other types of disorders that although they result in a scientific discovery do not stop from alternating the dynamics of the subject's thinking.

Here the context has the tendency to close in the family environment because it is the problem to be addressed, this limitation becomes a limitation for the complex analysis, but it is necessary to generate ordered cognitive processes in relation to the complexity that emerges in the context. In that order of ideas, the delimitation of the context has to do with: the affective environment, the composition of the family, socioeconomic conditions, educational level of the parents, communication between family members, index of risks of abuse between members of the family. This aspect has a certain relationship with the Complex Environmental Systems, proposed by Matteucci, and Buzai, [6].

The context in which a family operates establishes guidelines and family relationship rules, facilitating certain dispositions, interests and possibilities. Family patterns, means, needs and functions change with the passage from one stage to the next. Family development entails continuous changes in the context to which they must adapt, but when the family system is experiences normal problematic situations and does not have the ability to face them or they have run out, the family goes into crisis. From a systemic perspective, crises are dysfunctions or family pathologies that are classified into 3 levels: family children, family-couple, family-social environment (Caritas, Spanish, 2002).

This description of the family context will suffice to establish analysis criteria when addressing the context problem in relation to the dynamics of violence. Related this to violence as a cultural factor framed in the social and political discourse.

"Both the international discourse on the prevention of violence and the texts supporting permanent campaigns are part of the public discourse on prevention and intervention of violence. In this case the public discourse of prevention is understood as a rhetorical discourse or deliberate or intentional discourse that has as its main characteristic, the use of discursive-persuasive processes and as a habitual context are the public-political spheres. (...). (Lucaites, Condit \& Caudill, 1998) [4].

According to Fisas Vicenç, "the culture of violence is" culture "to the extent that over time it has been internalized and even sacralized by broad sectors of many societies, through myths, symbolisms, policies, behaviors and institutions, and despite having caused pain, suffering and death to millions of beings." (Aguilar, 2016)

\section{CATHEGORY 1: THE TERM VIOLENCE FROM THE NON-DUAL PERSPECTIVE}

Due to the term violence, Gonzales and Molinares present a definition to exercise a strong critical relationship process:

The term violence has received various meanings to describe multiple and different processes in which man is involved, and always identifies a victim and an offender. [1]

In addition to the cultural conception of violence that is 
supported by Cartesian dualistic thinking and the opinion of the role of the violent subject in society.

Cartesian dualism identifies a set of philosophical and scientific postulates developed in the Renaissance (...) Descartes said that "the mind can act independently of the brain" (...), which implies that the soul exists without dependence on the body. In describing the passions of the soul (...) also, he stated that psychology had as a matter of study, fundamentally, the soul or the mind (...) [13]

One of the great problems presented by the conception of violence is directly related to the duality implied by the term, directly related to the role of the victim and the perpetrator in the cycle of violence, this would always imply the conception of guilty and innocent which is part of the free exercise of law and not of psychology, in the present century it tends to be illogical and certainly subjective that this problem can be addressed based on medieval signifiers and with a strong linear tendency that prevent the free exercise of therapeutic performance in any of the disciplines of science that has this competence except those that make use of these terms in function of their object of study as the law does, having violence as a punishable act worthy of punishment.

But in the particular case of Psychology, where its function is beyond the punishment or reward of a socially accepted act or not, this simplistic tendency is little admissible, in the words of Bretano:

In this way, neither the natural sciences are body sciences, nor is psychology the science of the soul (...) as if it designates an essential substrate for psychic phenomena. Thus, the sciences in general describe phenomena and, in particular, the empirical character of psychology lies in the description of psychic phenomena. [10]

Under the criterion that violence is a psychic phenomenon susceptible of being analyzed without taking into account the old dualistic conception, this will be the optics of analysis to address the problem of violence due to the consequent openness that this strategy becomes in favor of the analysis; that is to say, generating a non-dualistic approach to the term violence allows us to see the set of cause-effects and their nuances that emerge from the context in which a violent act occurs and not two nonspecific roles such as victim and victimizer.

In this perspective the subject that violates is a simple link in the chain of causes and effects, and the subject that is violented has the same characteristics as the previous one. Therefore, for psychology the field of study of both subjects, tends to be more objective in terms of a varied set of causes, which generate the behavior patterns of the roles and not vice versa as the problem is conventionally analyzed.

For the psychologist, this maximum perspective is vital if one constantly insists on the processes of formation to avoid the phenomena of transference and countertransference in the psychological consultation.

The other perspective of the term violence has to do with the types of violence to be analyzed, the first that emerges as the most visible of all is physical violence, the second relates to psychological violence: the first is necessary to strip it of the concept of gender since the violence of the feminine also becomes an important factor when it comes to relating the physical damage caused by the behavior patterns that are imposed in the family formation process.

It is worth emphasizing that as it is the case in specific regions of the world such as Spain, the tendency to personal injury and the death of women is alarming.

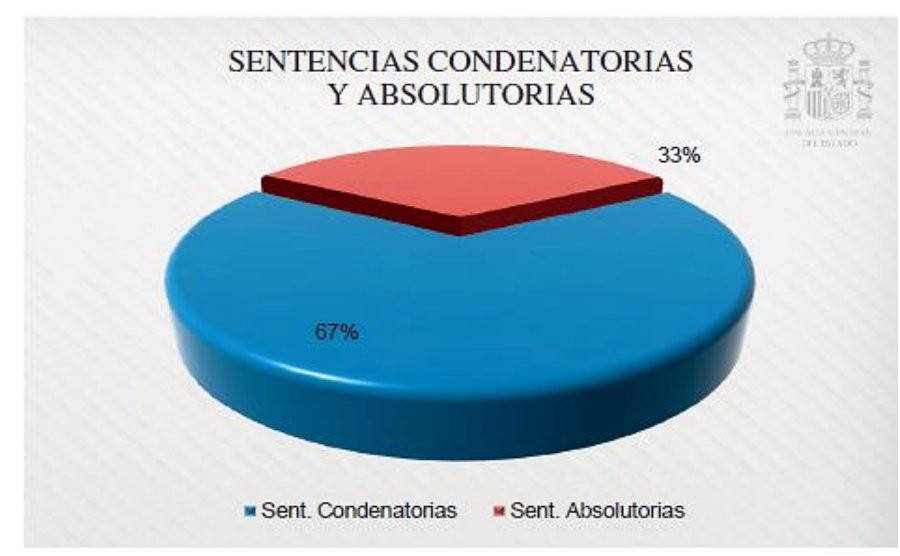

Fig. 3. Test statistics, convictions and acquittals. [11]

Source: Observatorio de violencia de género, contra la mujer. (2013).

Of the total number of sentences by crime $(45,306), 30,461$ -67.23 per 100 have been comdemning - and 14,845-32.77 per 100 have been acquittal. Of the convictions, they have been so by the defendant's $13,105-43.02$ per 100. (Ministry of Justice, 2014).

First analysis in the application of the pre model: category 2. Psychological or physical violence

But despite the publicity surrounding this phenomenon, it is only being approached from the dualistic configuration that prevents us from seeing it from a broad scientific perspective, without being mediated by the yellowish or media trade conceptions.

It is talked then of psychological or symbolic violence, that is, the ability to impose the validity of meanings by means of signs to the point that other people identify with them. This type of violence takes many forms, much more frequent than physical violence. They are more subtle, less obvious and indirect. In addition, when the meanings and values of the powerful are tamely accepted, there is no need to pay salaries, uniforms and weapons of a more expensive and uncomfortable repressive body. [8]. 
The second characteristic has to do with physical violence as an obvious and no longer symbolic element that leaves deep psychological traces and injuries of different types in the body.

The dualistic conception of victim / victimizer that has highly complicated characters will not be assumed, preventing the analysis of the complexity of the phenomenon by generating the signaling of one of the parties, as mentioned earlier in the dissertation on duality, in addition to the relevance of the matter of the positive or the negative, the condemnable or not condemnable is in the level of morality and law, aspects of which in the first instance at least, psychology will have to distance itself to make use of the greatest possible objectivity in the analysis of the problem, for the application of the predesigned model that allows a better understanding of this phenomenon in the causal context.

Once the categories, concepts and terms to be used are defined, it is necessary to deal with the context.

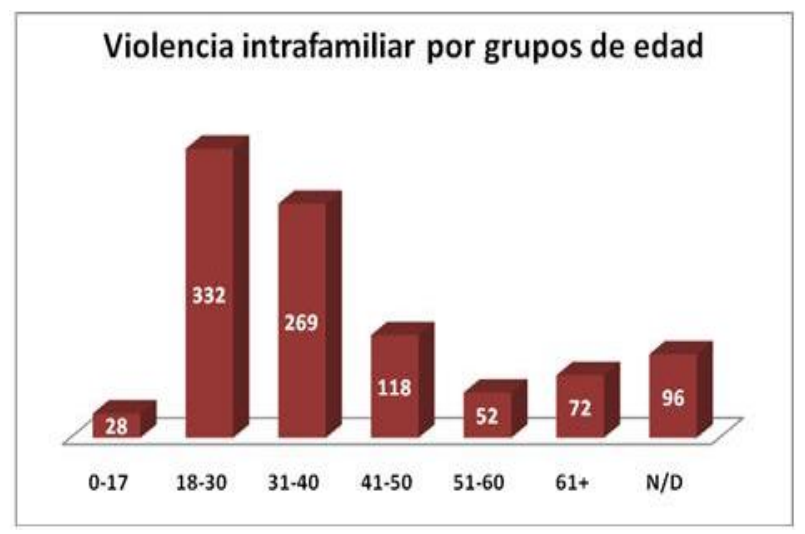

Fig. 4. Gender violence (women). January- April 2013.

Source: Observatorio de violencia de género, contra la mujer. [11]

As for age, the women between 18 to 30 and 31 to 40 years, are the ones who dare to denounce.

As for the municipalities, Soyapango occupies the first place, with 132 complaints, followed by Usulután, with 64 and Jiquilisco with 31 , place where the complaint was received from María L. the woman attacked by her couple. [11]
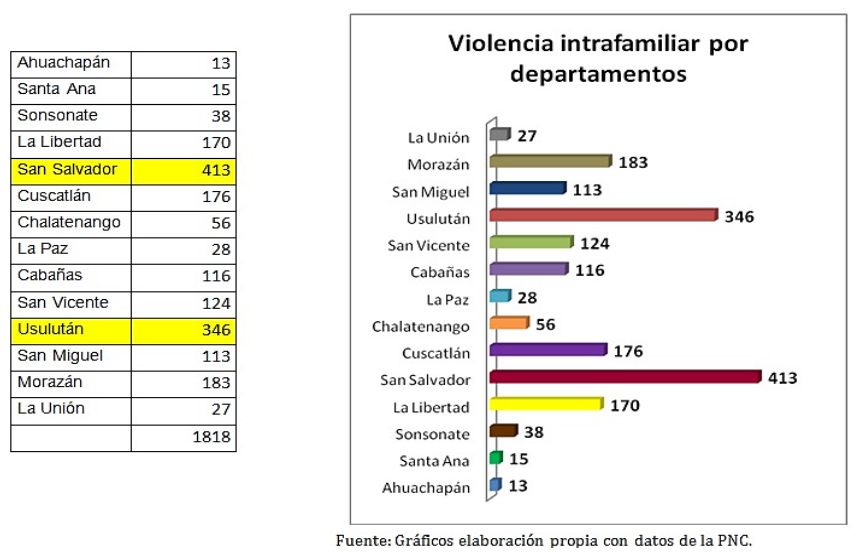

Fig. 5. Family violence.

Source: Observatorio de violencia de género, contra la mujer. (2013).

\section{Violence and gender violence.}

The process of applying the term violence has the tendency to be seen from the perspective of the extremes, defined the extreme as the importance that a theme has depending on the conveniences and the paradigmatic tendency of the moment.

«Violence is an ambiguous term, the meaning of which is established through political processes. The types of events that are classified vary according to whom provides the definition and who has greater resources to disseminate and make their decision apply»

And at this end there is the feminine violence that in the seventies was almost invisible to the states that did not use effective intervention programs and even more, that did not even visualize it as a first-order problem in society.

This fact is related to a diametral change of policies in the nineties where the tendency was a systematic denunciation, which in the 21st century tends to generate processes of organization and massification of increasingly global programs and lines of intervention.

"It is clear that in recent times there has been a certain process of social awareness about the seriousness of violence against women and the great obstacle it poses for democratic coexistence between men and women. However, we believe that the problem is still far from being solved.

From then until now, a new denomination has been proposed to address this serious reality, the concept of gender violence. In this regard, it should be noted that the European Commission Unit responsible for equal opportunities has developed a glossary ("100 words for equality. Glossary of terms relating to equality between men and women", 1999) which intends, among other things, to facilitate the work of the member states in the promotion of equality between women and men through a common understanding of the terms in this regard, and which, among many other terms, defines gender, sexist or sexual violence as "All types of violence exercised through recourse or threats of resorting to physical force or emotional blackmail; including rape, mistreatment of women, sexual harassment, incest and pedophilia".[12]

Although gender violence is not at all a new phenomenon, its recognition, its visibility, and, therefore, the step of being considered from a private issue to a social problem, is relatively recent.

This is the trend that Jerome Skolnick refers to and that well underlines in his contribution as an ambiguous term whose meaning is established through political processes. 
"This tendency that obeys criteria of a conventional and arbitrary nature, also has a background of interests that are woven around the dynamics of intervention, in other words, the massification of the defense of gender violence towards women is visible only when the political environment is conducive to this happening, creating ambiguities in the processes of policy application and ignoring alternative phenomena such as the passive violence of women towards men and also towards children, who, being a potentially active actor of the violent act, is not re-educated so that she is not.

This way of addressing the problem points to the dual conception of the meaning of the term violence, generating a multitude of ambiguities and paradigmatic blunders that prevent us from seeing the origin of the problem, it is not true that the violence factor can be repressed only with jurisprudential elements, nor is it that prevention alone stops the consequences of generations after generations of violent acts vehiculized by both the man (phenomenon of physicalpsychological violence) and woman (phenomenon of psychological-physical violence). "

The difficulty also lies in the identification of the phenomenon with gender, this being the initial element of the pre-paradigmatic model of epiphenomenological ecology, it is necessary to mention that the phenomenon of violence is entangled in a dualistic anomie or anarchy generating two different subjects that contradict permanently, as are the victim and the perpetrator. Defined in this way, the problem of violence is simple and it is enough to impose the penalty on the offender so that everything ends up there apparently. Violence then goes beyond the act it cross-sections and is part of the language, thereby intoxicating the language. Romano. [9].

Third analysis in the application of the pre model: category 3 . Elements of the metaphenomenon.

If Fig. 1 is observed. The range of domestic violence is greater between the ages of 18 and 30, but in relation to statistics, one might ask: "if this is the rank with the highest rate of violence, what happened in the previous ranks and with the prevention system that should have been applied?" Or as it is common in the states, laws were imposed to minimize the effects of a problem that goes beyond the simple application of the law to the alleged perpetrator.

And the supposed category is underlined because or one did not have to play the victim's role before being a victimizer? And going even further, are the patterns of training and behavior not transmitted generationally without review and reflection processes from the family that allow the violence factor to decrease?

The role of the state goes far beyond that of being a simple executor of the law, it must be a guarantee state that allows the development of intervention strategies in a permanent dynamic that regularize the processes for conflicto solution through education. Seen from that perspective, the violence factor is a metaphenomenon that implies chains of cause effects that must be analyzed at an interdisciplinary level permanently and accurately. Here are some:

\section{Behavioral patterns accepted from the family.}

\section{Aggressive role of parents.}

\section{Unwanted children}

\section{Violent parenting patterns}

\section{Heritage}

Fig. 6. Elements of the metaphenomenal violence. Source: self made.

\section{Behavioral patterns accepted from the family.}

2. Aggressive role of parents.

\section{Unwanted children.}

4. Violent parenting patterns.

\section{Inheritance.}

These five elements constitute a first approach to violence as a metaphenomenon.

A set of warp relationships between these elements arises, which determine the way in which violence begins and how it is forming an aggressive personality type, which naturally can be inclined to violent acts, if it is stimulated from the social context that it inhabits Let us bring to the area of analysis the example of domestic violence in Fig. 2 called domestic violence.

San Salvador with 413 points and Usulután with 349 points are the Peruvian provinces where the rate of violence against women is the highest, the statistics, although useful, tend to close the angle of vision of the problem, although the measurement is correct only the analysis about the problem at all helps to reveal the nuances of the problem in its real dimension, so this type of statistics and the way they are used correspond to suitable models to respond to international policies or demands that generate reactions in the population and that further root the dual conception in the collective and therefore leave the roots of the problem hidden.

"It is a fact that women around the world suffer violence. Physical, psychological, sexual violence, by society, their bosses, their relatives. Macho violence. Violence is not only 
blows and is found in any corner of the world, in any collective. Even at home. And it is women, and not men, who are at greater risk of suffering it in the domestic or family environment, according to the latest Report of the World Health Organization (WHO) on Violence and Health. The study indicates that 30\% of women around the world suffer gender violence from their partners and $35 \%$ will suffer it, in the couple or outside it, at some time in their lives. The General Director of the WHO, Margaret Chan, strongly stated that violence against women has become "a global health problem of epidemic proportions", while global health systems "can and should do more" for the victims. "[11].

Although the analysis is correct and the United Nations conception is correct, the problem remains unfocused, it is not only gender violence that produces gender violence, they are a set of factors from childhood, to the configuration of family and the conception of a couple that is rooted in the unconscious through family parenting patterns, which produce highly reactive and violent citizens, as occurs almost everywhere in the globe. Aspect that (Fizas, 1998) stands out [3]

In other words, metaphenomenon becomes permanently invisible both in the cultural ideology and in those who run some entities that are dedicated to the prevention of family, gender, social violence, among others, becoming a problem of great complexity for the community. Aspect that is introduced in the language, according to [9].

\section{CONCLUSIONS}

It is necessary to understand that violence can be analyzed from a complex perspective, it is not enough to remain in dual comparisons that only generate problems when applying both national and international policies, biasing the true nature of the phenomenon, it is necessary to go further, allowing discover the warp of causes effects that are woven into the dynamics of the violence factor both at family and gender level.

It is necessary to generate reflection and discussion about policies, in relation to the prevention of the physical and psychological violence factor in those countries that present greater risk factors. The proposed analysis aims to broaden the perspective on this great phenomenon on scientific bases and not on legal assumptions, where psychology plays a central role in generating intervention processes that are closer to reality. In this regard. [5] refers to:

La construcción de una cultura de paz y desarrollo sostenible es uno de los objetivos principales del mandato de la UNESCO. [5].

The context in this statistical analysis is completely disconnected from the reality of the problem of violence against women, because we do not know that there is a metaphenomenal universe that, although it is not susceptible of being measured at least with the limitations presented by the statistics applied in Type 1 science, it exists to the extent that the problem is associated with various contexts. In Figure 2 this statement is better explained by linking all the elements of the pre model to the metaphenomenal universe.

\section{REFERENCES}

[1]R, Arana, y I, Molinares, "La violencia en Colombia. Una mirada particular para su comprensión de cómo percibimos la violencia social a gran escala y hacemos invisible la violencia no mediática". Rev. Inv y Desarrollo. Vol.18, no.2, (pp.346-369), 05, 2010. [Online]. Available: http://www.scielo.org.co/scielo.php?pid=S0121$32612010000200007 \&$ script $=$ sci_abstract\&tlng $=$ pt

[2]F. Capra, La trama de la vida. Una nueva perspectiva de los sistemas vivos. Barcelona, España: Editorial Anagrama, 1998. p.57.

[3]V, Fizas. Cultura de paz y gestión de conflictos. España: Icaria y UNESCO, 1998. p. 408.

[4]J. Lucaites, C, Condi, y S. Caudill, Comtemporary Rhetorical Theory. New York: Guilford Press, 1998.

[5] UNESCO, (2019, octubre 10). Cultura de Paz y No Violencia. Construir la paz en la mente de los hombres y de las mujeres. [Online]. Available: https://es.unesco.org/themes/programas-construir-paz.

[6] D, Matteucci, y G, Buzai. Sistemas Ambientales Complejos: herramientas de análisis espacial. Buenos Aires, Argentina: Editorial Eudeba, 1998. Pp. 219-248. [Online]. Available: https://ridaa.unq.edu.ar/bitstream/handle/20.500.11807/665/16R2002v9n18.pdf?sequence=1\&isAllowed $=\mathrm{y}$

[7] J, González. Diccionario de filosofía. Chile: Editorial EDAF, 2010. p. 165.

[8]C, Ramírez. La inteligencia perdida de la verdad real a la verdad de la razón estudio sobre la epistemología y la inteligencia. Costa Rica: Editorial Ágora, 2002. p. 82.

[9]G, RomanoLa intoxicación lingüística: el uso perverso de la lengua. España: Ediciones intervención cultura, 2012. p 32.

[10] J, Vargas. Fenomenología y psicología Pura. Un estudio de la vía psicológica en Edmund Husserl. Santa fe de Bogotá: Ediciones el Bosque, 1999. p. 24.

[11] Observatorio de violencia de género, contra la mujer. (Mayo 20 2013). Asesinadas por violencia de género. Fiscales coordinadores y delegados para materias específicas. Ministerio Igualdad. Estadísticas y documentos. [Online]. Available: https://violenciagenero.igualdad.gob.es/violenciaEnCifras/victimasMort ales/fichaMujeres/

[12] F, E Bosch y V, A y Pérez, V, Ferrer. La violencia de género: De cuestión privada a problema social. Rev. Universitat Illes Balears. Vol 9, no.1, (pp.7-19), 05, 2010. [Online]. Available: https://www.redalyc.org/pdf/1798/179818244002.pdf

[13] G, M, M Novoa, "Algunas consideraciones sobre el dualismo en psicología Universitas Psychologica". Rev. Univer Psychologica, vol. 1, núm. 2, (pp. 71-80), 12, 2002. [Online]. Available: https://www.redalyc.org/pdf/647/64701209.pdf 


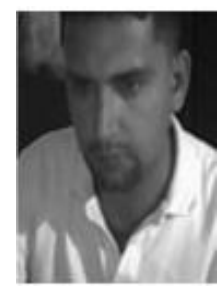

Jhon Jairo Mosquera Rodas. Was born on November 16, 1975 in Pereira, Risaralda (Colombia). B.A in Spanish and Audiovisual Communication, Universidad Tecnologica de Pereira, Risaralda, Colombia, 2003. Master in Education, Catholic University of Manizales. Manizales, Caldas, Colombia, 2009. Doctorate in education sciences from Cuauhtémoc University, Aguascalientes, Mexico, 2019. Research field: research epistemology. He has served as a teacher in the middle and upper levels in the Colombian education system, has served as an Advisory Professor in the Master of Education of the Catholic University of Manizales. Evaluator at the undergraduate and Master's level at the Cooperative University of Colombia. He is currently a research professor at the Cooperative University of Colombia; in social and human sciences, advisor of national and regional projects. Mag. Mosquera, is a reviewer for the International Journal of Social Sciences at the University of Illinois. Outstanding student of the Technological University of Pereira. Member of the common Ground international research network.

ORCID: https://orcid.org/0000-0002-3455-8470

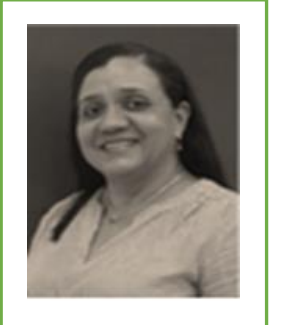

María Beatriz Valencia Bonilla. Was born on May 17, 1969 in Pereira, Risaralda (Colombia). Doctor in Economic Sciences - University of Havana (2019), Master in Economic and Financial Administration Technological University of Pereira (2001), Bachelor of Technical Areas -

Technological University of Pereira (1998), Industrial Technologist - Technological University of Pereira (1993). Associate Professor and researcher at the Technological University of Pereira, Faculty of Technology, attached to the Industrial Technology Program from May 1996 to date, also works as a professor and researcher at the Cooperative University of Colombia, Faculty of Economic, Administrative and Accounting Sciences, attached to the Business Administration Program from February 2016 to date. Extensive professional, work and teaching experience in the accounting and financial field. Member of the Scientific Council of the IV

International Congress Knowledge Management for Sustainable Development CIGECYT. Ecuador, June 2020. ORCID: https://orcid.org/0000-0001-5758-4391 